\title{
Cyclin-Dependent Kinase Inhibitor Protein
}

National Cancer Institute

\section{Source}

National Cancer Institute. Cyclin-Dependent Kinase Inhibitor Protein. NCI Thesaurus.

Code C18492.

A protein that plays a role in the inhibition of cyclin-dependent kinases. 